\title{
A Study on Pragmatic Failures in Nonverbal Communication in Intercultural Communicative Context
}

\author{
GUO Zi-rui \\ Ningbo Dahongying University, Ningbo, China

\begin{abstract}
In the intercultural communication, people often ignore the nonverbal behavior when they talk to others. With the raid progress of modern traffic and tools of communication, people's contacts have become increasingly frequent with different regions and countries. The research on pragmatic failures in nonverbal communication allows people to understand its nature and eliminate some unnecessary misunderstanding. This paper aims at finding out the root causes about pragmatic failures in nonverbal communication in the intercultural communication, and providing several sensible recommendations.
\end{abstract}

Keywords: intercultural communication, nonverbal communication, pragmatic failures

\section{Introduction}

Intercultural communicative refers to the communication between people from different cultural backgrounds, which is carried out by verbal behaviors and nonverbal behaviors. In the intercultural communication, people not only have verbal behaviors but also nonverbal behaviors of rich content. Nonverbal communication is a kind of stimulation which is brought about by human and environmental instead of verbal behavior in the communicative context. These stimulations have promising potential value and significance for message sender and recipient.

Like verbal communication, nonverbal communication is also an instrument of interaction for people to send information, exchange ideas, and express emotion, which have special functions. According to statistics, more than $65 \%$ of language information is expressed by nonverbal forms. In addition, in intercultural communication, it is common to occur on pragmatic failures in nonverbal communication, because of different cultures. Therefore, the study of pragmatic failures in nonverbal communication is very necessary in intercultural communication.

\section{Pragmatic Failures and Nonverbal Communication}

\section{Definition of Pragmatic Failures}

The concept of pragmatic failures is suggested by Jenny Thomas (1983), the famous pragmatists in the United Kingdom. She defined it as "the inability to understand what is meant by what is said" (p. 91). She divided the pragmatic failures into two categories: pragmalinguistic failure and social pragmatic failures. They belong to the limits of language study, but the latter is sociocultural, while the former is linguistic.

Since then, pragmatic failure is one of the hot spots in pragmatics research. The domestic and foreign

GUO Zi-rui, bachelor, English Department, Ningbo Dahongying University. 
scholars define the pragmatic failures from several different angles. HE Zi-ran (1997) points out that the pragmatic failure is not an error in language use, but the failure of talking untimely. Expression does not conform with the custom; inappropriate manner of speaking will lead to bad communication effectiveness. QIAN Guan-lian (1989) believes that speakers use the correct sentence in verbal communication, but violate personal relations norms, social conventions unconsciously, ignoring the target and out of time, which are called pragmatic failures.

Nowadays pragmatic failure in cross-cultural communication has become an important field of pragmatics. In the intercultural communication, pragmatic failures happen not only between the native and non-native speakers, but also on the same language from different cultures. Thus, intercultural pragmatic failures should be defined that intercourse have not been achieved as designed in intercultural communication, because any part of communicator lacks accurate understanding and ability to use verbal or nonverbal information effectively.

\section{Nature of Pragmatic Failures in Nonverbal Communication}

Nonverbal communication is also called body language communication. The process of transferring information through gestures, body language, facial expressions, and using the methods does not belong to the verbal language. Many researchers believe that almost $2 / 3$ in their daily communication is through nonverbal communication to pass information.

\section{Analysis of Pragmatic Failures in Cross-Cultural Nonverbal Communication}

\section{Nonverbal Pragmatic Failures in Kinesics}

Kinesics refers to the research in gestures, facial expression, postures, and so on. In cross-cultural communication, pragmatic failures in nonverbal communication often take place in a countenance, eye contact and gesture, for instance, known as the special pose "Scissorhands", which compare the pose to "V" with the forefinger and middle finger. It means victory in China. Some people do not pay attention and often back to the audience with this pose. However, in the eyes of the West, this gesture is obscene gestures.

Facial expression in the most can show human emotions of nonverbal behavior. Statistical data show that humans have 250,000 kinds of facial expressions. Because of cultural differences, facial expressions have different meanings in each of different countries. Such as the familiar smile, it means pleasure or friendliness in the United States. While in China, it can represent happiness and embarrassment. In order to avoid misunderstanding, in intercultural communication, people need to comprehend the meaning of facial expressions properly.

The eyes are the windows of the mind. It can show personal feelings and emotions. In intercultural communication, eye contact can often cause misconception, for example, British and American people attach great importance to look directly at their eyes open while talking. If there is no direct eye contact, they will think the person is afraid, despise, and deceive. On the contrary, in China, for the purpose of expressing respect and complaisance, both parties to the conversation have direct eye contact. As a result, if the Americans do not understand the habit of Chinese eye contact, they may think it is an impolite and unfriendly behavior to look away from their stare.

\section{Nonverbal Pragmatic Failures in Proxemics}

Proxemics refers to people's perception and use of space. Hull (1987), American social psychologist, found four proxemics: public distance, social distance, personal distance, and intimate distance. These kinds of 
distances have universality in different cultures, but it is likely to vary by culture under certain circumstances between people. As for proxemics, communicators from different cultures have difference in understanding and using.

In the United States, intimate distance is only suitable for parents, children, and couples. Same sex friend rarely keep this distance, or it will get extremely upsetting of both parties. But it often occurs in Chinese culture, especially in same sex friend, they can hug each other. The behavior will make Americans feel confused.

\section{Nonverbal Pragmatic Failures in Paralanguage}

Pragmatic failure in paralanguage refers to the improper silence, speech, or incorrect use of some nonverbal voice. In the attitude towards silence, people in China are very different from many English-speaking countries. Anglo-American countries are not used to Chinese' noisy in the library and theater. However, on other occasions, they are confused about Chinese' overmuch silence. Chinese people often use silence to refuse others' questions, but in the opinion of British and American, it is impolite and a biggest insult to the questioner.

If people use semantic behaviors incorrectly that can be misleading, such as whistles. In China, if a man whistles at a young lady, it will be considered as hooliganism and ulterior motives. Quite the opposite, in the United States, it praises her beauty and express favor, which hopes to attract her attention.

\section{Nonverbal Pragmatic Failures in Chronemics}

Comparing with verbal communication, nonverbal communication has concealed, and time concept cannot be seen. If people only recognize their own time concept in culture, misunderstandings will happen. For example, in a foreign country, people have a rest on Sunday, but to worship in the Church. In China, influence of Buddhism and Taoism, Sunday does not make sense.

In addition, the attitude of the time varies greatly due to different cultures. When Chinese people receive invitations to visit a friend's home, they will come half an hour early. Even the female guests will help the hostess do the things they can. However, this will not happen in America. They are often a few minutes later than appointed time, so that the host does not feel embarrassed in making ready in time.

\section{Causes of Pragmatic Failures and Suggestions for Intercultural Communication}

\section{Causes for Pragmatic Failures in the Intercultural Communicative Context}

Cross-cultural pragmatic failures in nonverbal communication result from a variety of reasons. In intercultural communication, cultural difference is the most important. Especially in nonverbal communication, it often reflects different cultural identities and values between gestures. Because they do not understand or ignore values, social and cultural backgrounds with each other. There will be misunderstanding and communication barrier.

There are also some differences in ethical concept between Chinese and Westerners. China's ethic foundation is the family, which focus importantly linking to relation by blood and have a deep concept of native. On the thinking modes and behaviors, they used to emphasize collectivism as cultural. However, in the West, people value the individual independence, abstract, and theory. Therefore, in the West, people are advocating individualism, rarely accentuating the ethics, and developing their individual maximize potential to achieve their dreams. 


\section{Suggestions for Intercultural Communication}

It is necessary to set up the intercultural awareness. In communication, people should respect habits, culture, and customs of another nation. Do in Rome as Rome does and try to avoid pragmatic failures in nonverbal communication, because they do not understand other cultures.

It is necessary to develop cultural empathy and tolerance. In intercultural communication, people should realize that the culture has diversity and equality. They would respect each other's culture. Culture does vary from one another, but there should be no judgment of good or bad. Different countries and nations need to tolerate and learn from each other's culture. It is unwise to reject because of the conflict with the own culture.

\section{Conclusion}

Communication behavior consists of verbal language and nonverbal language. Sometimes people only use the verbal language or use just nonverbal language. But in order to get a broader and deeper intercourse, in the more circumstances, they must use two ways simultaneously and interchangeably, which convey complex information and express exquisite and colorful feelings. As a result, the study of pragmatic failures in nonverbal communication in intercultural communicative context should arouse high attention.

In nonverbal communication, an action, even an eye contact will contain replied meaning. Understanding the nonverbal difference between different cultures will help to avoid or reduce conflicts and obstacles, so as to get better communication across cultures. Larry A. Samovar (2000), who believes that through understanding the basic pattern of nonverbal language for one culture, people can study on cultural structure and value. Pass-previous research and study of nonverbal behavior, people can exclude an insular racial superiority. The culture shock in different nonverbal behaviors is more serious than the verbal behavior, which cannot be ignored.

Therefore, in intercultural communication, people should be aware of difference of nonverbal language to improve sensibility, to increase understandings and to raise validity for cross-cultural communication. Besides, people further raise nonverbal communication ability in intercultural communicative context.

\section{References}

Austin, J. L. (1962). How to do things with words. London: Oxford University Press.

Brown. P., \& Levinson. S. (1987). Some universals in language usage of politeness. New York: Longman Group Limited.

Canale, M., \& Swain, M. (1980). Theoretical bases of communicative approaches to second language teaching and testing. In Applied linguistics. London: Oxford University Press.

GENG, Z. H. (2010). 非言语交际中的语用失误分析 (An analysis on pragmatic failures in non-verbal communication). 现代 交际, $5,143$.

Gu, G. (1993). Politeness phenomenon in modern Chinese. Journal of Pragmatics, 14, 237-257.

Hall, E. T. (1959). The silent language. New York: Fawcett Publications.

HE, Z. R. (2001). 语用学概论 (Introduction to pragmatics). 长沙: 湖南教育出版社.

KANG, J. Y. (2010). 大学英语教学中培养学生跨文化交际能力的研究 (The research on cultivating students' intercultural communicative competence in college English teaching). 内蒙古: 内蒙古师范大学.

Leech, G. N. (1983). Principles of pragmatics. New York: Longman Group Limited.

LI, Y. S. (2004). 跨文化非语言交际语用失误研究 (Study on pragmatic failure in cross-cultural non-verbal communication). 武汉: 华北科技大学.

Thomas, J. (1983). Cross-cultural pragmatic failure: Applied linguistics. London: Oxford University Press.

Ungerer, F., \& Schmid, H. (2003). An introduction to cognitive linguistics. Beijing: Foreign Language Teaching and Research Press. 
Wright, A. (1987). How to communicate successfully. America: Cambridge University Press.

XIONG, X. L. (1999). 认知语用学概论 (An introduction to cognitive pragmatics). 上海: 上海外语教育出版社.

ZHOU, F. F., \& TANG, D. G. (2006). 跨文化交际语境中的非言语交际语用失误分析 (Pragmatic failures in nonverbal communication: A perspective of intercultural communicative context). 湖南科技学院学报, 1, 27. 